\title{
Morphometric analysis of Harpodon nehereus, Harpiosquilla raphidea, and Scylla serrata in the coastal waters of Tarakan, North Kalimantan, Indonesia
}

\section{GAZALI SALIM ${ }^{1, \vartheta}$, KUN RETNO HANDAYANI ${ }^{2}$, SUTRISNO ANGGORO ${ }^{3}$, AGUS INDARJO ${ }^{4}$, AGUNG DHAMAR SYAKTI ${ }^{5}$, ABDUL JABARSYAH IBRAHIM ${ }^{1}$, JULIAN RANSANGAN ${ }^{6}$, LUKMAN YUDHO PRAKOSO ${ }^{7}$}

${ }^{1}$ Department of Aquatic Resource Management, Faculty of Fisheries and Marine Science, Universitas Borneo Tarakan. Jl. Amal Lama No. 1, Tarakan 77115, North Kalimantan, Indonesia. Tel./fax.: +62-551-2052558, vemail: axza_oke@yahoo.com

${ }^{2}$ Representative of Central Java Province, Ombudsman of the Republic of Indonesia. J1. Siwalan No. 5, Semarang 50242, Central Java, Indonesia ${ }^{3}$ Department of Aquatic Resource Management, Faculty of Fisheries and Marine Science, Universitas Diponegoro. Jl. Prof. H. Soedarto, S.H, Tembalang, Semarang 50275, Central Java, Indonesia

${ }^{4}$ Department of Marine Science, Faculty of Fisheries and Marine Science, Universitas Diponegoro. Jl. Prof. H. Soedarto, S.H, Tembalang, Semarang 50275, Central Java, Indonesia

${ }^{5}$ Department of Fisheries and Marine Science, Universitas Jenderal Soedirman. J1. Dr Soeparno No. 63, Purwokerto Utara, Banyumas 53122, Central Java, Indonesia

${ }^{6}$ Borneo Marine Research Institute, Universiti Malaysia Sabah. Jl. UMS, Kinabalu 88400, Sabah, Malaysia

${ }^{7}$ Universitas Pertahanan Indonesia. IPSC Area, Sentul, Bogor 16810,West Java, Indonesia

Manuscript received: 10 August 2020. Revision accepted: 26 September 2020.

\begin{abstract}
Salim G, Handayani KR, Anggoro S, Indarjo A, Syakti AD, Ibrahim AJ, Ransangan J, Prakoso LY. 2020. Morphometric analysis of Harpodon nehereus, Harpiosquilla raphidea, and Scylla serrata in the coastal waters of Tarakan, North Kalimantan, Indonesia. Biodiversitas 21: 4829-4838. The Bombay duck (Harpodon nehereus), harpiosquillid mantis shrimp (Harpiosquilla raphidea), and giant mud crab (Scylla serrata) are among the commercially important fishery resources in Tarakan Island, North Kalimantan, Indonesia. This requires sustainable fisheries management to be in place since these resources have now become the main targets of fishing industry. However, sustainable fisheries management of these species is difficult because less is known about the species particularly its condition, fatness, and well-being. Hence, the current study was conducted to analyze the morphometric characteristics in order to deduce fishing pressure of the fish species in Tarakan waters. Data collection was achieved through field between September 2017 and April 2018. Morphometric characteristics (length, weight, width, and thickness) were collected throughout the sampling period. The length-weight relationship and condition factor were then estimated using the morphometric measurements. The data were then statistically analyzed either or combination of $t$-test, Chi-square, and the Mann-Whitney tests. The study revealed that all the three fish species $(H$. nehereus, Ha. raphidea, and $S$. serrata) populations in Tarakan waters were dominated by male individuals (M:F ratio; 1:0.81; 1:0.63; and 1:0.66, respectively). The length-weight analysis showed all fish were found to be smaller in size and exhibited negative allometric growth patterns. The analysis of condition factor also showed that the fish were dominated by flat and very flat body shapes. The current study suggests that the fish species may encounter some kinds of ecological disturbances that selectively removed female fish and larger individuals from the populations. However, more studies are needed to accurately identify those factors so that plans to effectively address the root cause could be incorporated in the sustainable fishery management tools of the fish resources.
\end{abstract}

Keywords: Condition factor, ecological disturbances, fisheries resources, morphometrics, sex ratio

\section{INTRODUCTION}

Fisheries resources consist of various types of organisms, such as fishes, shells, crabs, shrimps, mammals, etc. However, species diversity is varied among locations and seasons. Species availability is strongly dependent on habitat suitability(Asadi et al. 2016). Furthermore, the suitability of aquatic habitat for fish species is determined by various environmental parameters (Hashemi et al. 2015). Unfortunately, environmental conditions also keep changing because of seasonal dynamics. Thus, each location has unique characteristics that lead to variation in fish composition as an effect of its ecological and seasonal conditions (Glińska-Lewczuk et al. 2016).
Tarakan City is a small island located in the Northern Borneo, Indonesia. The city has a total area of $657.33 \mathrm{~km}^{2}$, covering $250.80 \mathrm{~km}^{2}$ of land area and $406.53 \mathrm{~km}^{2}$ of marine area (Statistics Tarakan Municipality 2018). The length of the coastline is approximately $65 \mathrm{~km}$ (Prihartanto and Roem 2016). With this vast marine area and long coastline, Tarakan City has high potential to develop its economy based on the sustainable exploitation fisheries resources.

The waters of Tarakan are included in the SCS-SFM (Sulu-Celebes Sea Sustainable Fisheries Management) Project (Prasetyo et al. 2014). Unfortunately, illegal fishings are still rampantly occurring (Madjid et al. 2018). Thus, the risk of overexploitation of these fisheries resources is profoundly high. 
Among the fish resources found in the coastal area waters of Tarakan City are the Bombay duck (Harpodon nehereus), the giant harpiosquillid mantis shrimp (Harpiosquilla raphidea), and the giant mud crab (Scylla serrata). These three species occupy different habitats within the coastal areas of Tarakan including deep sea, brackish water, and mangrove ecosystems. These species are economically valuable and have become fishing targets of local fishermen (Firdaus 2010; Widigdo et al. 2017; Mulyono et al. 2018).

Harpodon nehereus is a typical fish from Tarakan that is often consumed both in fresh and dried forms (Nugroho et al. 2015). Several locations on Tarakan Island, such as at Pantai Amal and Juata have been suggested to be the spawning grounds of the Bombay duck (Nugroho et al. 2017).

In Tarakan, the giant harpiosquillid mantis shrimp is considered bycatch. Thus, during fishing activity, mantis shrimp are discarded (Kalalo et al. 2015). Mantis shrimp are usually caught during the fishing of Bombay duck. However, in some other regions, mantis shrimp are commercially exploited for its high economic value as an export commodity (Arifin et al. 2014). This suggests that the exploitation of mantis shrimp in Tarakan waters has the potential to be improved.

The giant mud crab is an economically valuable resource that inhabits mangrove ecosystem and it often becomes the target of commercial fishing (Widigdo et al. 2017). In Tarakan, the mud crab has also become an aquaculture commodity, especially in traditional ponds (Iromo et al. 2018). However, the culture of mud crab is generally carried out only for fattening, while the gravid crabs are obtained from the wild catch (Jahan and Islam 2016). This emphasizes the importance of mud crabs to the local community.

Considering the importance of the abovementioned species, study concerning their biological condition is needed. Thus, the present study aims to analyze the morphometric characteristics and sex ratio of Bombay duck
(H. nehereus), giant harpiosquillid mantis shrimp ( $\mathrm{Ha}$. raphidea), and giant mud crab ( $S$. serrata) in the waters of Tarakan City in order to understand the growth status and their fishing pressure.

\section{MATERIALS AND METHODS}

\section{Sampling site}

The sampling was conducted in Juata waters of Tarakan Island, North Kalimantan, Indonesia (Figure 1) from September 2017 to April 2018.

\section{Data collection}

Sampling and data collection methods varied according to species. The sample collection of the Bombay duck (Figure 2a) was carried out by a field sampling using trawl net at 1.5 inches mesh size (common fishing practice in Tarakan) with the help of fishermen. During the sampling period, about 147 specimens of Bombay fish were successfully collected. The data recorded during the sampling included total length and bodyweight of the fish.

Sampling of mantis shrimp (Figure 2b) was also done during the trawling the Bombay fish (mantis shrimp is a bycatch of Bombay fish fishing). During the study period, sampling of mantis shrimp was approximately 214 specimens were successfully collected in sampling. Total length, carapace length, and weight and $\mathrm{C} / \mathrm{L}$ ratio (carapace to total length) of each mantis shrimp were taken.

Sampling for mud crabs (Figure 2c) was carried out in the selected mangrove areas using 2 inches mesh size trap called the "ambau kurung". The traps baited with small fish were left overnight in the sampling stations. During the sampling period, 161 specimens of crab were successfully obtained. Then, measurements of carapace length and width, body weight, body thickness, T/L (thickness to length) ratio, and T/W (thickness to weight) ratio of each specimen were taken.

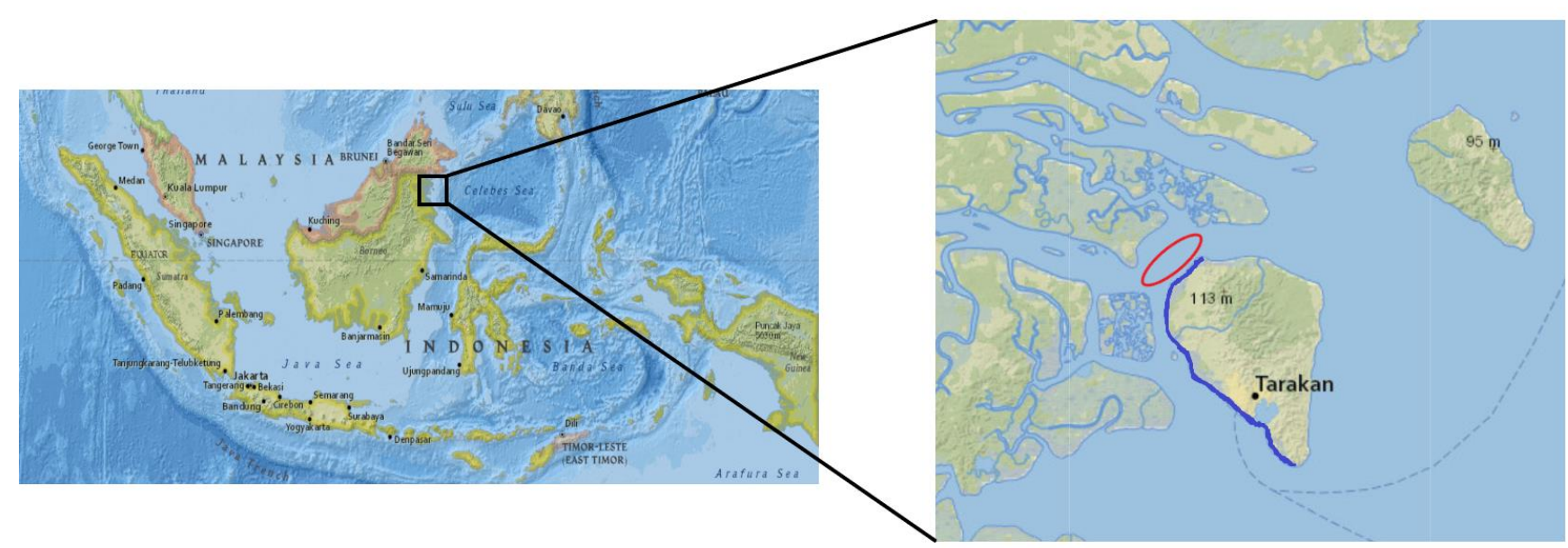

Figure 1. Sampling sites for Bombay duck and mantis shrimp (red circle), and mud crab (dark blue) in the coastal waters of Tarakan City, North Kalimantan, Indonesia 


\section{Data analysis}

Data analysis included sex ratio, growth pattern, condition factor, and fattiness. For growth patterns, the allometric growth index was determined using the regression analysis between length and weight. The following formula was used in the analysis of the lengthweight relationship (Effendie 1979); (Effendie 2002) :

$$
\mathrm{W}=\mathrm{a} \times \mathrm{L}^{\mathrm{b}}
$$

Where: W: weight; L: length/carapace; $a$ and $b$ : constants

From the formula above, the constant $b$ represents the allometric growth index. Fish are categorized as positively allometric when $b>3$, negatively allometric when $b<3$, and isometric when $b=3$ (Karachle and Stergiou 2012).

Santoso (2001) suggested that to find out whether the value of $b$ is different or not, from the equation of the length-weight relationship, it can be tested statistically using the t-student test, where the value of b describes the nature of fish growth.

Hypothesis: $\mathrm{H}_{\mathrm{O}}: \mathrm{b}=3$, isometric growth; $\mathrm{H}_{\mathrm{I}}: \mathrm{b} \neq 3$, allometric growth.

Decision-making rules: With the following conditions: $t$ count $<\mathrm{t}\left((\mathrm{a} / 2 ;(\mathrm{n}-2))\right.$, accept $\mathrm{H}_{\mathrm{O}}$, reject $\mathrm{H}_{\mathrm{I}}, \mathrm{t}$ count $>\mathrm{t}((\mathrm{a} / 2$; (n-2)), accept $\mathrm{H}_{\mathrm{I}}$, reject $\mathrm{H}_{\mathrm{O}}$.

Condition index of the crustacea and fish can be characterized into five criteria i.e. Very thin body shape (0.01-0.50), Thin body shape (0.51-0.99), Proportional/ ideal shape (1), Fat body shape (1.01-1.50), and Very fat body shape (>1.50) (Firdaus and Salim 2011; Salim 2013, 2015; Salim et al 2020a, 2020b; Firdaus et al. 2018, 2020; Indarjo et al. 2020a; 2020b). The length and weight data were also utilized to calculate the plumpness. The following formula was used to calculate Fulton's condition factor:

$$
K=\mathrm{W} / \mathrm{L}^{3} \times 100
$$

Where: $K=$ condition factor
The allometric growth was evaluated following Weatherley (1972), For isometric growth, methods suggested by Lagler (1949) and Effendie (1979) were used.

$$
K_{(\mathrm{TI})}=10^{5} x \frac{w}{L^{3}}
$$

Where: W: total weight (gram); L: total length (mm); $10^{5}$ : the equation was taken, so $\mathrm{K}_{\text {(TI) }}$ value is close to 1 .

The crab condition factor with allometric characteristic was obtained using equation (Weatherley 1972) as follow:

$$
K n=\frac{W}{W}
$$

$\mathrm{W}$ : total weight (gram); $\mathrm{w}$ : logarithm of total weight (gram); W: a $\mathrm{L}^{\mathrm{b}}$ obtained using the regression equation of length-weight correlation.

A slight modification of the formula was done by multiplying it by 1000 rather than 100 specifically for $S$. serrata in order to keep the index close to 1. Fulton's condition factor assumes that $K$ is close to $1 . K=1$ indicates that the length and weight are proportional, while $K<1$ indicates that the fish is slim and $K>1$ indicates that the fish is plump.

Furthermore, the fishes were grouped into 10 length classes. Then, the frequency and average value of Fulton's condition factor were analyzed for each length class.

Statistical analyses used in this study included Chisquare test, t-test, and Mann-Whitney rank test. The Chisquare analysis was carried out for the frequency distribution of length class and Fulton's condition factor between male and female fish. The Mann-Whitney test is a non-parametric statistical analysis method was used instead of the $t$-test in the event of data distribution is not normal. The Mann-Whitney rank test was carried out to compare the length, weight, $K$, and ratio of body measurements.

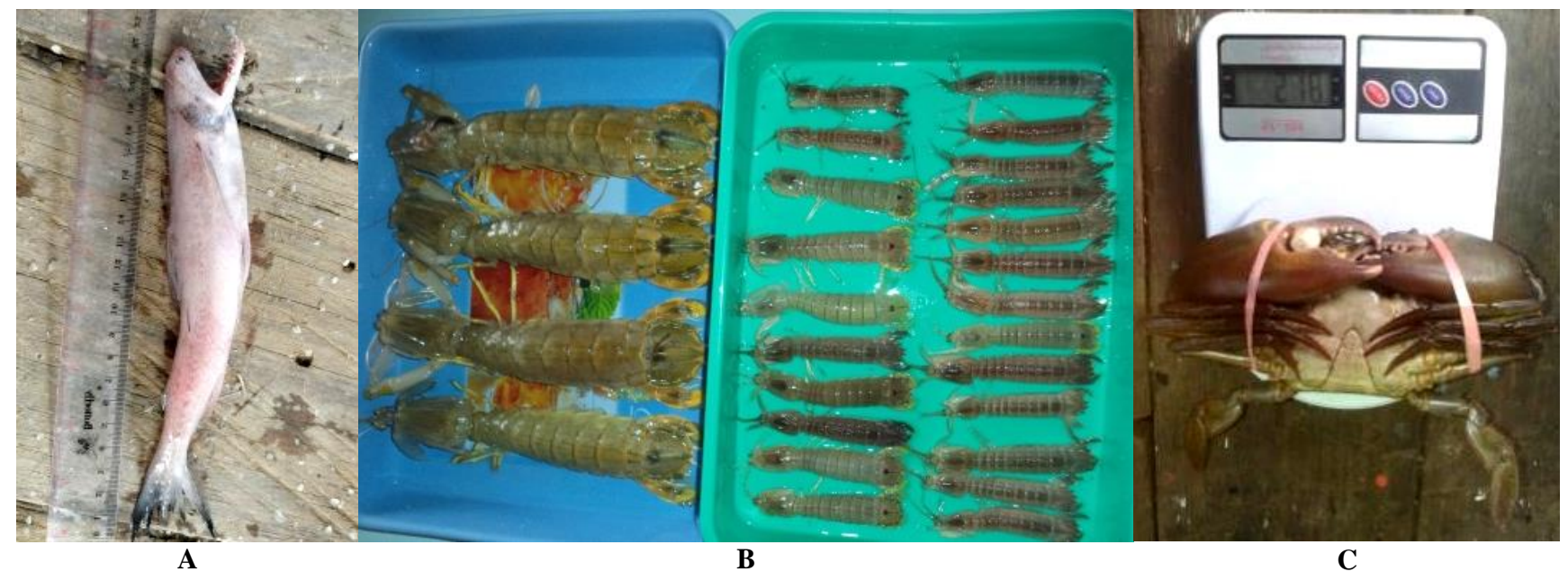

Figure 2. Fish species: A. Bombay duck (Harpodon nehereus), B. Mantis shrimp (Harpiosquilla raphidea), and C. Mud crab (Scylla serrata) 


\section{RESULTS AND DISCUSSION}

\section{Sex ratio of Harpodon nehereus, Harpiosquilla raphidea, and Scylla serrata}

The present study showed that the populations of $H$. nehereus, Ha. raphidea, and $S$. serrata in the Tarakan waters were found to be male-biased. The proportions of male and female fish for each species are presented in Table 1. This table shows that the population of female specimens was much lower than the male specimens. Despite being the closest ratio, the female population of $H$. nehereus was only $81 \%$ of the male population. The female population of $\mathrm{Ha}$. raphidea was $63 \%$ of the male population. The female population of S. serrata was $66 \%$ of the male population.

\section{Morphometric characteristics according to sex}

The analysis of morphometric characteristics of the fish species according to sex is presented in Table 2. The analysis showed that there were significant differences in the morphometrics of male and female $H$. nehereus, $\mathrm{Ha}$. raphidea, and $S$. serrata. The length and weight of $H$. nehereus were higher for female fish than for males. However, Ha. raphidea showed the opposite condition whereby the total length, carapace length, and weight were significantly higher for male compared to female shrimps. Nevertheless, the difference in the $\mathrm{C} / \mathrm{L}$ ratio was not significant ( $p>0.05)$. For $S$. serrata, total length, width, and thickness were found significantly higher $(p<0.05)$ in females compare to male crabs. Although the weight of male crabs was higher female crabs, the difference was not significant $(p>0.05)$. However, analyses of the $\mathrm{W} / \mathrm{L}$ ratio, $\mathrm{T} / \mathrm{L}$ ratio, and $\mathrm{T} / \mathrm{W}$ ratio showed significant differences among crabs of different sexes.

\section{Morphometric characteristics and condition factor according to sex}

The results of the length and weight relationship and Fulton's condition factor are presented in Table 3 and Table 4 , respectively. It was found that the fish species $(H$. nehereus, $H a$. raphidea, and $S$. serrata) exhibited negative allometric growth patterns regardless of sex.

The condition factor analysis indicated that there was no significant difference $(\mathrm{p}>0.05)$ in Fulton's condition factor of all the fish species. The analysis also showed that the average $K$ index of males and females of $H$. nehereus was similar. However, since the Mann-Whitney test is based on the rank, Fulton's condition factor between male and female fish was suggested to have not significant differences. Based on the frequency distribution of fish plumpness (Table 5), it could be concluded that the population of $H$. nehereus, $H a$. raphidea, and $S$. serrata in Tarakan waters mostly had flat body shape. Fish with Proportional body shape was only noted in $S$. serrata males. The Chi-square test showed that there were significant $(\mathrm{p}<0.05)$ differences in the proportion of body shape between males and females for H. Nehereus, Ha. raphidea and $S$. serrata.

The results of frequency distribution analyses of length classes and Fulton's condition factors of $\mathrm{H}$. nehereus, $\mathrm{Ha}$. raphidea and $S$. serrata are presented in Tables 6, 7, and 8, respectively.

It was found that the dominant length of $H$. nehereus was within the range of $22.4-23.5 \mathrm{~cm}$ (Table 6). However, the dominant class of the male fish was within the upper classes while the females were within the lower classes. Statistical analysis of the proportion length-frequency between male and female fish was not significantly different $\left(\chi^{2}=64.395 ; p=0.157>0.05\right)$. Further analysis on Fulton's condition factor $(K)$ within length classes showed some variations, especially the third and fourth classes. However, the Chi-square analysis of $K$ between sexes, found the variations were not significantly different $\left(\chi^{2}=\right.$ $49.00 ; p=0.939>0.05)$. The analysis revealed that the average $K$ value was higher for male populations compared to the females in all classes.

Analysis of the length-frequency distribution of the male and female shrimps showed that the shrimp population was mainly dominated by small specimens within the length class 12.6-15.2 cm (Table 7). The Chi-square test analysis showed that the variations in the length were significantly different $\left(\chi^{2}=150.860 ; p=0.000<0.05\right)$. Analysis of Fulton's condition factor could only be carried out for the first, second, and third classes. The other classes could not be analyzed due to data insufficiency. The Mann-Whitney test showed that there were no significant differences in the $K$ values within the classes. However, the variations of the $K$ value between sexes over length classes showed no significant differences ( $\mathrm{U}=38,50 ; p=0.352>0.05$ ).

Analysis of the length-frequency distribution (Table 8) of crabs showed that the male and female specimens did not have certain trends of domination. However, the fifth class (length range: $68.6-72.5 \mathrm{~cm}$ ) was the range in which both male and female crabs were dominant. Statistical analysis revealed that the length-frequency distribution of crab population showed was not a significant difference $\left(\chi^{2}=50.795 ; p=0.796>0.05\right)$. The Mann-Whitney test for the $K$ indices within the length classes showed significant differences between male and female crabs in the third through the eighth classes, respectively. It was also noted that the $K$ value in each class was higher for the male population compared to the female population. The MannWhitney test of the $K$ values between sexes over the length also showed no significant differences ( $\mathrm{U}=36.00$; $p=0.288>0.05)$.

\section{Discussion}

The data obtained in the present study indicate that the populations of $H$. nehereus, $H a$. raphidea, and $S$. serrata in the waters of Tarakan City were dominated by male individuals, respectively. Moreover, the proportion of females in the population of respective fish species was considered low. This finding was contrary to the finding of previous study which reported that the population of $H$. nehereus in Tarakan waters consisted of $56.8 \%$ females and $43.2 \%$ males (Perdana et al. 2016). Generally, wild fish population is always comprised of more females over males. However, male-biased populations may also naturally occur in certain conditions, such as in the early life of shrimp (Fryxell et al. 2015). 
Table 1. Sex ratio of Harpodon nehereus, Harpiosquilla raphidea, and Scylla serrata in Tarakan waters

\begin{tabular}{|c|c|c|c|c|c|c|}
\hline \multirow{2}{*}{ Species } & \multicolumn{2}{|c|}{ Male } & \multicolumn{2}{|c|}{ Female } & \multirow{2}{*}{$\begin{array}{c}\text { Total } \\
\text { abundance }\end{array}$} & \multirow{2}{*}{$\begin{array}{c}\text { Sex ratio } \\
\text { (M:F) }\end{array}$} \\
\hline & Abundance & Proportion & Abundance & Proportion & & \\
\hline H. nehereus & 81 & $55.1 \%$ & 66 & $44.9 \%$ & 147 & $1: 0.81$ \\
\hline Ha. raphidea & 131 & $61.2 \%$ & 83 & $38.8 \%$ & 214 & $1: 0.63$ \\
\hline S. serrata & 97 & $60.2 \%$ & 64 & $39.8 \%$ & 161 & 1:0.66 \\
\hline
\end{tabular}

Table 2. Morphometric characteristics of Harpodon nehereus, Harpiosquilla raphidea, and Scylla serrata according to sex [range (average $\pm \mathrm{SD})]$

\begin{tabular}{|c|c|c|c|c|}
\hline Species & Parameters & Male & Female & Statistic* \\
\hline \multirow[t]{4}{*}{ H. nehereus } & \multirow[t]{2}{*}{ Total length } & $18,50-24,50$ & $19,30-28,40$ & $1671,000.00$ \\
\hline & & $21,79 \pm 1,44^{\mathrm{a}}$ & $23,06 \pm 1,90^{\mathrm{a}}$ & 0.000 \\
\hline & \multirow[t]{2}{*}{ Weight } & $37,00-100,00$ & $39,00-142,00$ & $1814,500.00$ \\
\hline & & $61,88 \pm 11,93^{\mathrm{a}}$ & $72,48 \pm 20,41^{\mathrm{a}}$ & 0.001 \\
\hline \multirow[t]{8}{*}{ Ha. raphidea } & \multirow[t]{2}{*}{ Total length (L) } & $10,00-35,10$ & $10,40-35,70$ & $4037,500.00$ \\
\hline & & $14,01 \pm 4,13^{\mathrm{a}}$ & $12,92 \pm 2,74^{\mathrm{a}}$ & 0.002 \\
\hline & \multirow[t]{2}{*}{ Carapace length (C) } & $1,60-6,50$ & $1,80-6,00$ & $4339,000.00$ \\
\hline & & $2,50 \pm 0,70^{\mathrm{a}}$ & $2,33 \pm 0,48^{\mathrm{b}}$ & 0.012 \\
\hline & \multirow[t]{2}{*}{ Weight } & $4,40-165,50$ & $4,50-181,50$ & $4203,000.00$ \\
\hline & & $16,1 \pm 26,10^{a}$ & $11,71 \pm 19,06^{\mathrm{a}}$ & 0.005 \\
\hline & \multirow[t]{2}{*}{$\mathrm{C} / \mathrm{L}$ ratio } & $0,14-0,26$ & $0,15-0,22$ & $5301,000.00$ \\
\hline & & $0,18 \pm 0,01^{\mathrm{a}}$ & $0,18 \pm 0,01^{\mathrm{a}}$ & 0.745 \\
\hline \multirow[t]{14}{*}{ S. serrata } & \multirow[t]{2}{*}{ Total length (L) } & $53,50-85,00$ & $62,00-92,00$ & $1452,000.00$ \\
\hline & & $65,92 \pm 7,90^{\mathrm{a}}$ & $73,54 \pm 7,01^{\mathrm{a}}$ & 0.000 \\
\hline & \multirow[t]{2}{*}{ Width (W) } & $73,00-124,00$ & $89,00-177,00$ & $1598,500.00$ \\
\hline & & $95,38 \pm 11,86^{\mathrm{a}}$ & $106,52 \pm 14,62^{\mathrm{a}}$ & 0.000 \\
\hline & \multirow[t]{2}{*}{ Thickness (T) } & $27,00-48,00$ & $32,00-49,00$ & $2007,500.00$ \\
\hline & & $35,37 \pm 4,77^{\mathrm{a}}$ & $37,92 \pm 3,73^{\mathrm{a}}$ & 0.000 \\
\hline & \multirow[t]{2}{*}{ Weight } & $113,00-490,00$ & $135,00-365,00$ & $2705,000.00$ \\
\hline & & $219,63 \pm 89,09^{\mathrm{a}}$ & $217,23 \pm 52,09^{\mathrm{a}}$ & 0.168 \\
\hline & \multirow{2}{*}{$\mathrm{W} / \mathrm{L}$ ratio } & $1,27-1,56$ & $1,30-2,19$ & $2278,000.00$ \\
\hline & & $1,45 \pm 0,04^{\mathrm{a}}$ & $1,45 \pm 0,12^{\mathrm{a}}$ & 0.004 \\
\hline & \multirow[t]{2}{*}{$\mathrm{T} / \mathrm{L}$ ratio } & $0,49-0,66$ & $0,47-0,56$ & $1252,500.00$ \\
\hline & & $0,54 \pm 0,02^{\mathrm{a}}$ & $0,52 \pm 0,01^{\mathrm{b}}$ & 0.000 \\
\hline & \multirow[t]{2}{*}{$\mathrm{T} / \mathrm{W}$ ratio } & $0,34-0,42$ & $0,23-0,40$ & $2034,500.00$ \\
\hline & & $0,37 \pm 0,02^{\mathrm{a}}$ & $0,36 \pm 0,02^{\mathrm{b}}$ & 0.000 \\
\hline
\end{tabular}

Notation: *Statistical analysis with Mann-Whitney test. Different letters in the same row indicate significant difference

Table 3. Length and weight relationships of Harpodon nehereus, Harpiosquilla raphidea, and Scylla serrata according to sex

\begin{tabular}{|c|c|c|c|c|}
\hline \multirow{2}{*}{$\frac{\text { Species }}{H . \text { nehereus }}$} & \multicolumn{2}{|r|}{ Male } & \multicolumn{2}{|c|}{ Female } \\
\hline & $\mathrm{W}=0.0785 \mathrm{~L}^{2.1602}$ & $\left(\mathrm{R}^{2}=0.5571 \& \mathrm{r}=74.64 \%\right)$ & $\mathrm{W}=0.0787 \mathrm{~L}^{2.1665}$ & $\left(\mathrm{R}^{2}=0.4784 \& \mathrm{r}=69.17 \%\right)$ \\
\hline Ha. raphidea & $\mathrm{W}=0.0070 \mathrm{~L}^{2.8343}$ & $\left(\mathrm{R}^{2}=0.9706 \& \mathrm{r}=98.52 \%\right)$ & $\mathrm{W}=0.0067 \mathrm{~L}^{2.8573}$ & $\left(\mathrm{R}^{2}=0.9085 \& \mathrm{r}=95.32 \%\right)$ \\
\hline S. serrata & $\mathrm{W}=0.0012 \mathrm{~L}^{2.8836}$ & $\left(\mathrm{R}^{2}=0.8735 \& \mathrm{r}=93.46 \%\right)$ & $\mathrm{W}=0.0208 \mathrm{~L}^{2.1491}$ & $\left(\mathrm{R}^{2}=0.7463 \& \mathrm{r}=86.39 \%\right)$ \\
\hline
\end{tabular}

Table 4. Fulton's condition factor and sex-based differences of Harpodon nehereus, Harpiosquilla raphidea, and Scylla serrata in Tarakan waters

\begin{tabular}{lccc}
\hline \multicolumn{1}{c}{ Species } & Male & Female & Statistic* $^{*}$ \\
\hline H. nehereus & $0.40-0.80$ & $0.30-0.90$ & $2315,500.00$ \\
Ha. raphidea & $0.60 \pm 0.09^{\mathrm{a}}$ & $0.58 \pm 0.12^{\mathrm{b}}$ & 0.946 \\
& $0.30-0.60$ & $0.30-0.70$ & $1476,500.00$ \\
S. serrata & $0.46 \pm 0.06^{\mathrm{a}}$ & $0.46 \pm 0.07^{\mathrm{b}}$ & 0.181 \\
& $0.50-1.00$ & $0.40-0.70$ & $579,000.00$ \\
\hline
\end{tabular}

Note: *Statistical analysis with Mann-Whitney test 
Table 5. The plumpness index and body shape of Harpodon nehereus, Harpiosquilla raphidea, and Scylla serrata according to sex

\begin{tabular}{|c|c|c|c|c|c|c|c|}
\hline \multirow{2}{*}{ Plumpness index } & \multirow{2}{*}{ Body shape } & \multicolumn{2}{|c|}{ H. nehereus } & \multicolumn{2}{|c|}{ Ha. raphidea } & \multicolumn{2}{|c|}{ S. serrata } \\
\hline & & $\mathbf{M}$ & $\mathbf{F}$ & $\mathbf{M}$ & $\mathbf{F}$ & M & $\mathbf{F}$ \\
\hline$<0.5$ & Very flat & 2 & 7 & 58 & 39 & - & 2 \\
\hline $0.5-0.99$ & Flat & 79 & 59 & 73 & 44 & 96 & 62 \\
\hline 1 & Proportional & - & - & - & - & 1 & - \\
\hline $1.01-1.50$ & Rounded & - & - & - & - & - & - \\
\hline$>1.50$ & Very Rounded & - & - & - & - & - & - \\
\hline Total & & $81^{\mathrm{a}}$ & $66^{\mathrm{b}}$ & $131^{\mathrm{p}}$ & $83^{q}$ & $97^{x}$ & $64^{y}$ \\
\hline Statistics* & & $0.000^{\mathrm{a}}$ & 1.000 & $0.000^{p}$ & 1.000 & $0.000^{\mathrm{x}}$ & 1.000 \\
\hline
\end{tabular}

Note: *Statistical analysis with chi-square test

Table 6. Sex-based length-frequency distribution and Fulton's condition factor of Harpodon nehereus in Tarakan waters

\begin{tabular}{|c|c|c|c|c|c|}
\hline \multirow{2}{*}{ Class } & \multirow{2}{*}{ Length range } & \multicolumn{2}{|c|}{ Frequency } & \multicolumn{2}{|c|}{ Average condition factor } \\
\hline & & Male & Female & Male & Female \\
\hline 1 & $18.0-19.1^{\#}$ & 2 & - & $0,70 \pm 0.17^{\mathrm{a}}$ & - \\
\hline 2 & $19.1-20.2^{\ddagger}$ & 14 & 3 & $0,70 \pm 0.11^{\mathrm{a}}$ & $0,80 \pm 0.17^{b}$ \\
\hline 3 & $20.2-21.3^{\ddagger}$ & 14 & 10 & $0,60 \pm 0.09^{\mathrm{a}}$ & $0,60 \pm 0.09^{\mathrm{a}}$ \\
\hline 4 & $21.3-22.4^{\ddagger}$ & 20 & 12 & $0,60 \pm 0.07^{\mathrm{a}}$ & $0,60 \pm 0.13^{\mathrm{a}}$ \\
\hline 5 & $22.4-23.5^{\ddagger}$ & 22 & 16 & $0,50 \pm 0.08^{\mathrm{a}}$ & $0,60 \pm 0.12^{\mathrm{a}}$ \\
\hline 6 & $23.5-24.6^{\ddagger}$ & 9 & 15 & $0,60 \pm 0.08^{\mathrm{a}}$ & $0,50 \pm 0.08^{b}$ \\
\hline 7 & $24.6-25.7^{\#}$ & - & 3 & - & $0,50 \pm 0.10$ \\
\hline 8 & $25.7-26.8^{\#}$ & - & 6 & - & $0,60 \pm 0.18$ \\
\hline 9 & $26.8-27.9$ & - & - & - & - \\
\hline \multirow[t]{2}{*}{10} & $27.9-29.0^{\ddagger}$ & - & 1 & - & 0,40 \\
\hline & Total/Average & $81^{x \phi}$ & $66^{\mathrm{y}}$ & $0.60 \pm 0.09^{a^{*}}$ & $0.58 \pm 0.12^{\mathrm{a}}$ \\
\hline
\end{tabular}

Notation: ${ }^{\#}$ The number of samples was not sufficient for statistical analysis; ${ }^{\phi}$ Statistical analysis with chi-square; ${ }^{*}$ Statistical analysis with Mann-Whitney test; 'Statistical analysis with $t$-test. Different letters in the same row show significant difference

Table 7. Sex-based length-frequency distribution and Fulton's condition factor of Harpiosquilla raphidea in Tarakan waters

\begin{tabular}{|c|c|c|c|c|c|}
\hline \multirow{2}{*}{ Class } & \multirow{2}{*}{ Length range } & \multicolumn{2}{|c|}{ Frequency } & \multicolumn{2}{|c|}{ Average condition factor } \\
\hline & & Male & Female & Male & Female \\
\hline 1 & $10.0-12.6^{\ddagger}$ & 50 & 42 & $0.46 \pm 0.05^{\mathrm{a}}$ & $0.48 \pm 0.07^{\mathrm{a}}$ \\
\hline 2 & $12.6-15.2^{\ddagger}$ & 60 & 38 & $0.47 \pm 0.07^{\mathrm{a}}$ & $0.45 \pm 0.07^{\mathrm{a}}$ \\
\hline 3 & $15.2-17.8^{\ddagger}$ & 16 & 2 & $0.45 \pm 0.05^{\mathrm{a}}$ & 0.40 \\
\hline 4 & $17.8-20.4$ & - & - & - & - \\
\hline 5 & $20.4-23.0$ & - & - & - & - \\
\hline 6 & $23.0-25.6$ & - & - & - & - \\
\hline 7 & $25.6-28.2$ & - & - & - & - \\
\hline 8 & $28.2-30.8^{\#}$ & 1 & - & $0.40^{\mathrm{b}}$ & - \\
\hline 9 & $30.8-33.4^{\#}$ & 2 & - & $0.35 \pm 0.07^{b}$ & - \\
\hline \multirow[t]{2}{*}{10} & $33.4-36.0^{\ddagger}$ & 2 & 1 & $0.40^{\mathrm{b}}$ & $0.40^{\mathrm{b}}$ \\
\hline & Total/Average & $131^{x \phi}$ & $83^{y}$ & $0.46 \pm 0.06^{\mathrm{a}^{*}}$ & $0.46 \pm 0.07^{\mathrm{a}}$ \\
\hline
\end{tabular}

Notation: ${ }^{\#}$ The number of samples was not sufficient for statistical analysis; ${ }^{\phi}$ Statistical analysis with chi-square; *Statistical analysis with Mann-Whitney test; 'Statistical analysis with $t$-test. Different letters in the same row show significant difference

Table 8. Sex-based length-frequency distribution and Fulton's condition factor of Scylla serrata in Tarakan waters

\begin{tabular}{cccccc}
\hline \multirow{2}{*}{ Class } & \multirow{2}{*}{ Length range } & \multicolumn{2}{c}{ Frequency } & \multicolumn{2}{c}{ Average condition factor } \\
\cline { 2 - 6 } & & Male & Female & Male & Female \\
\hline 1 & $53.0-56.9^{\#}$ & 12 & - & $0,83 \pm 0.06$ & - \\
2 & $56.9-60.8$ & 16 & - & $0,71 \pm 0.11^{\mathrm{a}}$ & $0,63 \pm 0.08^{\mathrm{b}}$ \\
3 & $60.8-64.7^{\ddagger}$ & 18 & 7 & $0,74 \pm 0.07^{\mathrm{a}}$ & $0,56 \pm 0.07^{\mathrm{b}}$ \\
4 & $64.7-68.6$ & 18 & 9 & $0,67 \pm 0.07^{\mathrm{a}}$ & $0,57 \pm 0.08^{\mathrm{b}}$ \\
5 & $68.6-72.5^{\ddagger}$ & 16 & 14 & $0,73 \pm 0.13^{\mathrm{a}}$ & $0,54 \pm 0.09^{\mathrm{b}}$ \\
6 & $72.5-76.4^{\ddagger}$ & 5 & 13 & $0,70 \pm 0.12^{\mathrm{a}}$ & $0,54 \pm 0.07^{\mathrm{b}}$ \\
7 & $76.4-80.3$ & 6 & 10 & $0,80 \pm 0.09^{\mathrm{a}}$ & $0,49 \pm 0.04^{\mathrm{b}}$ \\
8 & $80.3-84.2^{\ddagger}$ & 4 & 7 & $0,75 \pm 0.10^{\mathrm{a}}$ & $0,50^{\mathrm{b}}$ \\
9 & $84.2-88.1^{\#}$ & 2 & 2 & $0,75 \pm 0.07^{\mathrm{a}}$ & $0,50^{\mathrm{b}}$ \\
\hline & $88.1-92.0^{\#}$ & - & 2 & - & $0.73 \pm 0.10^{\mathrm{a}^{*}}$ \\
\hline
\end{tabular}

Notation: ${ }^{\#}$ The number of samples was not sufficient for statistical analysis; ${ }^{\phi}$ Statistical analysis with chi-square; ${ }^{*}$ Statistical analysis with Mann-Whitney test; ${ }^{\ddagger}$ Statistical analysis with $t$-test. Different letters in the same row show significant difference 
The sex ratio of the Ha. raphidea obtained in the present study was not in agreement with the findings of previous studies. The global population structure of $\mathrm{Ha}$. raphidea was reported to have the tendency of femalebiased. For example, the population of $\mathrm{Ha}$. raphidea in Tanjung Jabung Barat exhibited a male: female ratio of 1:0.68 (Wardiatno and Mashar 2010), while in Andaman Sea, Thailand, the average ratio was reported to be $1: 1.54$ (Samphan and Ratanamusik 2018). However, studies also showed that the sex ratio of $\mathrm{Ha}$. raphidea can fluctuate causing a change in population structure from femalebiased to male-biased (Chandra et al. 2014; Kalalo et al. 2014; Salim and Wiharyanto 2015; Salim and Wiharyanto 2016). Nevertheless, the female-biased condition is still more common than male-biased.

The population of $S$. serrata in the waters of Tarakan City was also found to be male-biased with sex ratio (male: female) of 1:0.66. This finding was found to be consistent with the observations in other places. A study carried out in Bulungan, North Kalimantan showed a sex ratio of 1:0.79 (Widigdo et al. 2017) while the Persian Gulf and the Gulf of Oman showed a ratio between 1:0.13 to 1:0.69 (RezaieAtagholipour et al. 2013).

In nature, sex bias population in some fish species could occur during its life cycle. The proportion of male and female individuals may change any time during the new hatch, young, adult, and mature stages. The change may also occur as a result of dispersal and migration patterns (Szekely et al. 2014).

Skewed sex ratios could indicate the possibility of environmental disturbances within the habitat of the fish population that selectively removed or retained favorable individuals. For example, a change in temperature could induce sex differentiation (Budd et al. 2015), while some predators prefer female prey over males or vice versa (McKellar and Hendry 2011; Fryxell et al. 2015). Environmental pollution could also induce hormonal changes which may influence sex determination (Sanchez et al. 2011).

In some cases, the increase in the male population (or reduced female population) could be due to the selective fishing gear. According Froese (2006), noted that in their early stages the fishes grow in length in a greater ratio than they grow in other dimensions and their length-weight ratio, thus differs from what obtains among larger individuals. Finally, he noted that the variation in weight at a given size in the same species increases very much as the fish grows in length. Females fish are generally larger, resulting in an increased probability of capture during fishing, especially with the use of large net mesh size. Thus, a population that is actually female-biased can change to become male-biased over a prolonged uncontrolled fishing activity (Côté 2013). Changes in the sex proportion may also occur during mating season. The proportion of ready-to-mate males usually decreases during the mating season (Wacker et al. 2013). Unfortunately, it was unknown whether the current state of the observed sex ratio in the three fish species investigated in the present study was related to mating season or not. In the case of the
Bombay fish and the mantis shrimp, the trawl net used to catch them has a mesh size of 1.5 inches. However, it is difficult to ascertain if this mesh size selectively caught only the small-sized fish which mostly consist of male fish. Studies show that sex ratio within a fish population has wide implications for the population strength (Fryxell et al. 2015). According to Wacker et al. (2013), male-biased populations have been seen to exacerbate the competition between males for mates.

The present study also observed that the range of length and weight of Bomby duck (H. nehereus) in the waters of Tarakan City was relatively narrower than that in Kakdwip, West Bengal, which had a range of lengths between 7.3-32.1 cm and weighs between 2-250 $\mathrm{g}$ (Behera et al. 2015). However, previous study by Firdaus et al. (2013) showed that the growth of $H$. nehereus in Tarakan waters could reach maximum lengths of $33.847 \mathrm{~cm}$ for males and $35.743 \mathrm{~cm}$ for females. The length-weight relationship also showed positive allometric growth patterns $(b=3.4262)$ for the global population (Behera et al. 2015). However, the finding of the present study revealed that the growth pattern of the male and female fish was characterized by negative allometric ( $b$ values of 2.1602 and 2.2665), respectively. This was slightly different from the findings of previous observations of the species in Juata and Amal waters, which showed a $b$ value of 2.59 and 3.00, respectively (Taqwa et al. 2018). This implies that there is a possibility that individuals of the Bombay duck in Tarakan waters are getting smaller.

The male and female mantis shrimp ( $H a$. raphidea) populations in the waters of Tarakan were recorded to have average length of 14,01 $\pm 4,13 \mathrm{~cm}$ and 12,92 $\pm 2,74 \mathrm{~cm}$, respectively. A study in Malaysia recorded length distribution of 10.3 to $20.7 \mathrm{~cm}$ (average $15.9 \pm 3.35 \mathrm{~cm}$ ) and 10.4 to $22.2 \mathrm{~cm}$ (average $15.8 \pm 3.47 \mathrm{~cm}$ ) for male and female shrimps, respectively (Antony et al. 2014). In Thailand, the shrimp was recorded to range from 19 to 32 $\mathrm{cm}$ (average $27.39 \pm 2.17 \mathrm{~cm}$ ) for males and 22 to $33.5 \mathrm{~cm}$ (average $28.44 \pm 1.80 \mathrm{~cm}$ ) for females, respectively (Samphan and Ratanamusik 2018). This indicates that the mantis shrimp population in Tarakan waters consisted of smaller individuals than that in Malaysia and Thailand. However, the growth coefficients (2.8343 and 2.8573, respectively) of the male and female mantis shrimp populations in Tarakan waters, although slightly higher, are in agreement with the $b$ values $(2.4718$ and $2.5571 ; 2.7425$ and 2.4810, respectively) of the species in Malaysia (Antony et al. 2014) and Thailand (Samphan and Ratanamusik 2018). This implicates that individuals of $\mathrm{Ha}$. raphidea in Tarakan waters tend to have a smaller size but faster weight gain.

Previous studies on S. serrata in Bulungan showed that the carapace length was ranged from 40-89 $\mathrm{mm}$ and 32-91 $\mathrm{mm}$, respectively for male and female crabs, while the carapace width ranged from 59-128 mm and 53-122 mm, respectively (Widigdo et al. 2017). The study in the Persian Gulf and the Gulf of Oman showed the carapace width between 89.7-196.5 $\mathrm{mm}$ and 91.7-170.1 mm, respectively for male and female crabs (Rezaie-Atagholipour et al. 2013). 
The length-weight relationship analysis showed that the S. serrata in Tarakan waters had a negative allometric growth pattern. The $b$ values recorded at 2.8836 and 2.1491 , respectively for male and female crabs. This is in agreement with the finding (2.3968 and 3.2012 respectively) of Widigdo et al. (2017). Study by RezaieAtagholipour et al. (2013) also showed that the $b$ value of male giant mud crab was higher than for females (3.47 and $2.55)$, respectively. In comparison to these studies, it can be suggested that the weight growth rate of $S$. serrata in Tarakan waters was slower. Further consideration judged on the basis of $b$ values, it could suggest that environmental quality in Tarakan waters may not be in optimal condition to support the growth of giant mud crab. However, this phenomenon could also be caused by the intense fishing activity over a long period that selectively removes large size mud crab. In addition, high fishing frequency also means it does not provide sufficient time for young crabs to grow bigger.

Analysis of Fulton's condition factors $\left(\mathrm{K}_{\mathrm{n}}\right)$ of $H$. nehereus (0.40-0.80; 0.30-0.90, respectively), Ha. raphidea $(0.30-0.60 ; 0.30-0.70$, respectively) and $S$. serrata $(0.50$ $1.00 ; 0.40-0.70$, respectively) revealed that the species were characterized to have flat bodies. In this study, the use of Fulton's condition factor for determining length-weight parameters was preferred because of its exact and standardized value for length base weight reference. The use of relative weight to calculate condition factor was avoided since it resulted in the unstandardized weight reference and is highly relative to the population's condition. However, most of the studies concerning $H$. nehereus used relative weight as the preferred analytical method for condition factor (e.g. Firdaus et al. (2013) and Laga et al. (2015)).

The use of the relative condition factor is not comparable to Fulton's condition factor. By applying the relative condition factor, the fish population would always be dominated by the "thin/flat" and "fat/rounded" categories even though the weight distribution was different among populations, as proven by Chandra et al. (2015). Thus, it cannot be used as a reference condition for the global population.

A study carried out by Mulyono et al. (2013) showed an average Fulton's condition factor of 1.19 and 1.21 respectively for male and female shrimp in Banten Bay. These results were much higher than the findings of this study. This indicates that Ha. raphidea in Tarakan waters are less plump. This may be attributed to the environmental quality of the waters around Tarakan City but further study is needed to ascertain.

Mohapatra et al. (2010) studied the condition factor of $S$. serrata relating carapace width and weight using a hundred-based multiplier. The result showed that the condition factor of $S$. serrata was ranged from 0.0350 0.0719 and $0.0368-0.0671$, respectively for male and female crabs. However, data obtained in the present study showed that using carapace width to estimate the condition factor was less appropriate due to the increasing number of outliers. Study of Sentosa and Syam (2011) showed a much higher value but similar pattern i.e. the range of condition factors for females was wider than for males. The authors also noted that the frequency distribution for length class of $S$. serrata did not have certain size domination which is consistent with the results of the current study.

Overall, the sex ratios, length and weight ranges, length-weight relationships, and condition factors of $H$. nehereus, Ha. raphidea, and S. serrata in Tarakan waters were different from those in other places referred to in this study. The differences could be attributed to certain factors such as behavioral, spatial, and temporal variations or the impacts of environmental conditions. Some aquatic species are considered migratory. Migration may affect reproduction and/or feeding activity of the species. Migratory species may also inhabit different places depending on their life stages. This influences the spatial distribution of species and so as the morphometric characteristics (Olson et al. 2018). Spatial distribution can refer to horizontal or vertical movements, and in some migratory species, spatial variation occurs along with temporal variation (Arocha et al. 2017). Even though spatial and temporal variations may occur in fish species, this may not be appropriate in the current study since all three species exhibited low condition factors which imply that inappropriate environmental conditions may exist that affect the growth condition of fish. Disturbances in environmental conditions can reduce food availability which may result in insufficient supply of food availability hence hinder the growth performance of fish species in a particular environment (Lourenço et al. 2012). This condition may severely affect the sedentary species more than the migratory species.

Environmental condition is an important factor that affects growth rates because metabolism can potentially induce genetic modification (Besson et al. 2016). Various environmental stresses induce adaptation processes that cause morphological and genetic differentiation (Saleky et al. 2016). However, genetic modification requires a very long time to occur, but initial change can be foreseen in morphological modification. Fish condition indices such as the $b$ value and Fulton's condition factor represent the symptoms of food insufficiency (Koffi et al. 2014). Thus, there might be a possibility of higher rate of genetic differentiation in the populations of $H$. nehereus, Ha. raphidea, and $S$. serrata in Tarakan waters compared to regions.

In conclusion, the current study suggests that the populations of Bombay duck (Harpodon nehereus), giant harpiosquillid mantis shrimp (Harpiosquilla raphidea), and giant mud crab (Scylla serrata) in the Tarakan waters were found to be dominated by male individuals and are relatively smaller in body size compared to the same species occurring in other regions. The more males proportion in the population coupled with the low $b$ values and Fulton's condition factor of the three important fishery species investigated in the current study warrant a more thorough study to be conducted on the ecological parameters and the fishing activity in the Tarakan waters as to obtain fundamental scientific information for establishing effective sustainable fishery resource management in the area. 


\section{ACKNOWLEDGEMENTS}

The authors express gratitude to Student Management Resources of Waters, Faculty Fisheries and Marine Science, University of Borneo Tarakan, Indonesia.

\section{REFERENCES}

Antony PJ, Rahman MM, Rajkumar M, Yunus K, Khan SA. 2014 Relative growth of Harpiosquilla raphidea (Fabricius, 1798) (Crustacea: Stomatopoda) male and female populations. Sains Malays 43 (9): 1305-1310

Arifin MY, Supriyono E, Widanarni. 2014. Total hemocyte, glucose and survival rate of Mantis shrimp (Harpiosquilla raphidea) posttransportation with two different systems]. Jurnal Kelautan Nasional 9 (2): 111-119. DOI: 10.15578/jkn.v9i2.6207. [Indonesian]

Arocha F, Ortiz M, Evaristo E, Gutierrez X, Marcano LA. 2017. Spatial and temporal size/age distribution patterns of Albacore (Thunnus alalunga) in the Caribbean Sea and adjacent waters of the Western Central Atlantic from observer data of the Venezuelan longline fisheries. Collect Vol Sci Pap 73 (4): 1413-1423.

Asadi H, Sattari M, Eagderi S. 2016. Habitat suitability index of Barbus cyri (Heckel, 1843) in Tootkabon River, the South Caspian Sea basin, Iran. Casp J Environ Sci 14 (1): 33-42.

Behera S, Biswas BK, Kumar S, Gogoi R. 2015. Length-weight relationships and condition factors of Bombay Duck, Harpodon nehereus from estuarine region of Kakdwip, West Bengal. J Biol Innov 4 (2): 59-66.

Besson M, Aubin J, Komen H, Poelman M, Quillet E, Vandeputte M, van Arendonk JAM, de Boer IJM. 2016. Environmental impacts of genetic improvement of growth rate and feed conversion ratio in fish farming under rearing density and nitrogen output limitations. J Clean Prod 116: 100-109. DOI: 10.1016/j.jclepro.2015.12.084

Budd AM, Banh QQ, Domingos JA, Jerry DR. 2015. Sex control in fish: approaches, challenges and opportunities for aquaculture. J Mar Sci Eng 3: 329-355. DOI: 10.3390/jmse3020329

Chandra T, Latif AA, Kalalo A, Salim G. 2014. Study of Growth Aspects of Grandma Shrimp (Harpiosquilla raphidea) in the Juata Sea Waters of Tarakan City. Jurnal Harpodon Borneo 7 (2)): 81-86. DOI : 10.35334/harpodon.v7i2.108. [Indonesian]

Chandra T, Salim G, Wiharyanto D. 2015. Model populasi pendekatan pertumbuhan dan indeks kondisi Harpiosquilla raphidea waktu tangkapan pada pagi hari di perairan utara Pulau Tarakan [Population model of growth approach and Harpiosquilla raphidea condition index for morning catch time in the northern waters of Tarakan Island]. Jurnal Harpodon Borneo 8 (2): 122-131. DOI: 10.35334/harpodon.v8i2.133. [Indonesia]

Côté IM. 2013. Inadvertent consequences of fishing: The case of the sexchanging shrimp. J Anim Ecol 82: 495-497. DOI: 10.1111/1365 2656.12074

Effendie MI. 2002. Biologi Perikanan. Yayasan Pustaka Nusatama, Yogyakarta. [Indonesian]

Effendie M. 1979. Metode biologi perikanan. Yayasan Dewi Sri, Bogor. [Indonesia]

Firdaus M, Salim G, Cahyadi J, Weliyadi E, Bintoro G. 2020. Model and nature of growth of red snapper fish (Lutjanus argentimaculatus (Forsskål, 1775)) fishing catch of bottom fish pots in Bunyu waters, North Kalimantan. AACL Bioflux 13 (3): 1410-1421.

Firdaus M, Lelono TD, Saleh R, Bintoro G, Salim G. 2018. The expression of the body shape in fish species Harpadon nehereus (Hamilton, 1822) in the waters of juata laut, tarakan city, north kalimantan. AACL Bioflux 11 (3): 613-624. DOI: 10.5281/zonodo. 1250264

Firdaus M, Salim G. 2011. Mengkaji Populasi Ikan Puput (Ilisha elongata) yang berasal dari perairan Kota Tarakan. Harpodon 4 (1): 46-53. DOI: 10.35334/harpodon.v4i1.62. [Indonesia]

Firdaus M. 2010. Hasil tangkapan dan laju tangkap unit perikanan pukat tarik, tugu, dan kelong [Catches and catch rates of trawlers, monuments, and kelong fishing units]. Makara Teknologi 14 (1): 22 28. DOI: 10.7454/mst.v14i1.445. [Indonesia]

Firdaus M, Salim G, Maradhy E, Abdiani IM, Syahrun. 2013. Analisis pertumbuhan dan struktur umur ikan Nomei (Harpodon nehereus) di perairan Juata Kota Tarakan [Analysis of growth and age structure of Nomei (Harpodon nehereus) fish in the Juata waters of Tarakan City]. Jurnal Akuatika 4 (2): 159-173. [Indonesia]

Froese R. 2006. Cube law, condition factor and weight-length relationships: History, meta-analysis and recommendations. J Appl Ichthyol 22 (2006): 241-253. DOI:10.1111/j.1439-0426.2006.00805.x

Fryxell DC, Arnett HA, Apgar TM, Kinnison MT, Palkovacs EP. 2015. Sex ratio variation shapes the ecological effects of a globally introduced freshwater fish. Proc R Soc B Biol Sci 282: 20151970. DOI: $10.1098 / \mathrm{rspb} .2015 .1970$.

Glińska-Lewczuk K, Burandt P, Kujawa R, Kobus S, Obolewski K, Dunalska J, Grabowska M, Lew S, Chormański J. 2016. Environmental factors structuring fish communities in floodplain lakes of the undisturbed system of the Biebrza River. Water 8 (4): 146. doi: 10.3390/w8040146.

Hashemi SA, Ghorbani R, Kymaram F, Hossini SA, Eskandari G, Hedayati A. 2015. Fish species composition, distribution and abundance in Shadegan Wetland. Fish Aquac J 6: 1000128. DOI: 10.4172/2150-3508.1000128

Indarjo A, Salim G, Zein M, Septian D, Bija S. 2020a. The population and mortality characteristics of mangrove crab (Scylla serrata) in the mangrove ecosystem of Tarakan City, Indonesia. Biodiversitas 21 (8): 3856-3866. DOI: 10.13057/biodiv/d210855

Indarjo A, Salim G, Zein M, Soejarwo PA, Nugraeni CD, Bija S, Pham Y TH. 2020b. Characteristics of von Bertalanffy growth, allometric, condition index and mortality of Periophthalmus barbarus in Mangrove and Bekantan Conservation Area (KKMB), Tarakan, North Kalimantan. Indon J Mar Sci 25 (1): 31-38. DOI: 10.14710/ik.ijms.25.1.31-38

Iromo H, Jabarsyah A, Awaluddin. 2018. Reproduction of females mud crab (Scylla serrata) with thyroxine hormone supplementation in traditional ponds from North Borneo Indonesia. Int J Fish Aquat Stud 6 (3): 378-381.

Jahan H, Islam MS. 2016. Economic performance of live crab (Scylla serrata) business in the southwest coastal region of Bangladesh. Int $\mathbf{J}$ Fish Aquat Stud 4 (1): 453-457.

Kalalo A, Salim G, Wiharyanto D. 2015. Analisis populasi pertumbuhan allometri dan indeks kondisi Harpiosquilla raphidea waktu tangkapan siang hari di perairan Juata Kota Tarakan [Analysis of population growth allometry and Harpiosquilla raphidea condition index during daytime catchments in Juata waters Tarakan City]. Jurnal Harpodon Borneo 8 (2): 78-87. DOI: 10.35334/harpodon.v8i2.126

Karachle PK, Stergiou KI. 2012. Morphometrics and allometry in fishes. In: Wahl C (eds). Morphometrics. InTech, USA.

Koffi BK, Berté S, Koné T. 2014. Length-weight relationships of 30 fish species in Aby Lagoon, Southeastern Côte d'Ivoire. Curr Res J Biol Sci 6: 173-178. DOI: 10.19026/crjbs.6.5517.

Laga A, Affandi R, Muchsin I, Kamal MM. 2015. Growth and exploitation rate of the Bombay Duck (Harpodon nehereus Hamilton, 1822) (Fish: Synodontidae) in Tarakan Island Waters, Indonesia. Int J Sci Basic Appl Res 22 (1): 341-353.

Lagler KF. 1949. Studies in Freshwater Fishery Biology. JW Edwards, USA.

Lourenço S, Fernandes IM, Súarez YR. 2012. Spatial and temporal variation in population structure of Hemigrammus marginatus (Characiformes: Characidae) in streams of the Ivinhema River Basin, Brazil. Zoologia 29: 300-307. DOI: 10.1590/S198446702012000400003

Madjid MA, Pudjiatmoko S, Rafsanjani MAAH. 2018. Chlorophyll-a image as one of the guidelines for determining illegal fishing surveillance areas (Case study of North Kalimantan Province waters). Jurnal Keamanan Maritim. 4 (2): 67-86. [Indonesian]

McKellar AE, Hendry AP. 2011. Environmental factors influencing adult sex ratio in Poecilia reticulata: Laboratory experiments. J Fish Biol 79: 937-953. DOI: 10.1111/j.1095-8649.2011.03065.x

Mohapatra A, Mohanty RK, Mohanty SK, Dey SK. 2010. Carapace width and weight relationships, condition factor, relative condition factor and gonado-somatic index (GSI) of mud crabs (Scylla spp.) from Chilika Lagoon, India. Indian J Mar Sci 39 (1): 120-127.

Mulyono M, Patria MP, Abinawanto A, Affandi R. 2013. Length-weight relationship and condition factor in giant harpiosquillid Mantis shrimp, Harpiosquilla raphidea (Crustacea: Stomatopoda) in Banten Bay waters, Indonesia. Intl J Aquat Biol 1 (4): 185-187.

Mulyono M, Abinawanto, Mardiyono, Syam MY, Sudiarsa IN. 2018. Morphometric and genetic diversity of mantis shrimp Harpiosquilla 
raphidea from Karimata Strait and Java sea waters, Indonesia. AACL Bioflux 11 (6): 1681-1687.

Nugroho ED, Rahayu DA, Amin M, Lestari U. 2015. Morphometric characters of marine local fish (Harpodon sp.) from Tarakan, Northern Borneo. J Biol Res 21: 41-45. DOI: 10.23869/bphjbr.21.1.20153.

Nugroho ED, Vlorensius, Salurapa A. 2017. Spawning preferences and Nomei (Harpodon nehereus) fish habitat in Juata Sea waters in Tarakan Sea as a conservation effort. Biogenesis 5: 55-60. DOI: 10.24252/bio.v4i2.3434. [Indonesian]

Olson AP, Siddon CE, Eckert GL. 2018. Spatial variability in size at maturity of golden king crab (Lithodes aequispinus) and implications for fisheries management. R Soc Open Sci 5: 171802. DOI: 10.1098/rsos.171802.

Perdana I, Salim G, Weiliyadi E. 2016. Comparison of sex ratio, mortality and growth of Nomei (Harpadon nehereus) fish originating from fishermen caught in Juata City of Tarakan. Jurnal Harpodon Borneo 9: 133-142. DOI: 10.35334/harpodon.v9i2.170. [Indonesian]

Prasetyo AP, Nugroho D, Wudianto, Irianto HE, Purwanto. 2014. Initiation on ecosystem approach to fisheries management (EAFM): Case study on Tarakan Fisheries. Indon Fish Res J 20: 87-98. DOI: 10.15578/ifrj.20.2.2014.87-98

Prihartanto E, Roem M. 2016. Study of potential increase in settlements in coastal areas affected by abrasion by sensory utilization (Case study: Binalatung tourism beach, Tarakan City). Jurnal Harpodon Borneo 9: 123-126. DOI: 10.35334/harpodon.v9i2.168. [Indonesian]

Rezaie-Atagholipour M, Naderloo R, Kamrani E, Savari R. 2013. Preliminary biological information of Scylla serrata (Forskal, 1775) (Brachyura, Portunidae) in the Persian Gulf and Gulf of Oman: A conservation priority. Crustaceana 86: 322-335. DOI: 10.1163/15685403-00003174

Santoso, S. 2001. SPSS Versi 10.0 Mengolah Data Statistik Secara Profesional. PT. Elex Media Komputindo, Jakarta. [Indonesian]

Saleky D, Setyobudiandi I, Toha HA, Takdir M, Madduppa HH. 2016. Length-weight relationship and population genetic of two marine gastropods species (Turbinidae: Turbo sparverius and Turbo bruneus) in the Bird Seascape Papua, Indonesia. Biodiversitas 17 (1): 208-217. DOI: $10.13057 /$ biodiv/d170130.

Salim G, Wiharyanto D. 2015. Population analysis of endemic crustaceans of the grandma/pengko shrimp (Harpiosquilla raphidea) originating from Juata City Tarakan City. Hibah Penelitian Dosen Pemula /PDP, Kementrian Riset Teknologi dan Pendidikan Tinggi Republik Indonesia, Tahun 2015. DOI: 10.13140/RG.2.2.36540.39042. [Indonesia]

Salim G, Wiharyanto D. 2016. Analysis of population using the allometry growth model and sharing condition index Harpiosquilla raphidea North Waters of Tarakan Island. Seminar Nasional Simposium Nasional Kelautan Perikanan Universitas Hasanuddin, 2016. DOI: 10.13140/RG.2.2.24689.84320. [Indonesian]

Salim G. 2015. Analisis pertumbuhan allometri dan indeks kondisi caesio cunning didapatkan dari hasil tangkapan nelayan Kota Tarakan.
Jurnal Harpodon Borneo 8 (1): 35-42. DOI: 10.35334/harpodon.v8i1.125. [Indonesian]

Salim G. 2013. Nilai indeks kondisi dari ikan siganus javus berdasarkan hasil tangkapan nelayan di Perairan Juata Kota Tarakan. Jurnal Harpodon Borneo 8 (1): 37-42. DOI: 10.35334/harpodon.v6i1.99

Salim G, Indarjo A, Zein M, Prakoso LY, Suhirwan, Daengs AGS, Rukisah. 2020a. The allometric growth and condition index comparison of white shrimp (Litopenaeus vannamei) from fishpond and juata laut waters, Tarakan (Indonesia). The 3rd International Symposium Marine and Fisheries (ISMF) 2020. IOP Conf Ser Earth Environ Sci 564: 012009. DOI. 10.1088/1755-1315/564/1/012009.

Salim G, Indarjo A, Zein M, Prakoso LY, Suhirwan, Daengs, AGS, Rukisah, Bija S. 2020b. Analysis of allometric growth and condition index of tiger shrimp (Penaeus monodon) in Juata Laut Waters and Fishpond, Tarakan (Indonesia). The 3rd International Symposium Marine and Fisheries (ISMF) 2020. IOP Conf Ser Earth Environ Sci 564: 012010. DOI. 10.1088/1755-1315/564/1/012010.

Samphan P, Ratanamusik A. 2018. The length-weight relationship factor and sex-ratio of Mantis Shrimp (Harpiosquilla spp) in Andaman Sea of Satun, Thailand. Int J Agric Technol 14 (1): 61-71.

Sanchez W, Sremski W, Piccini B, Palluel O, Maillot-Maréchal E, Betoulle S, Jaffal A, Aït-Aïssa S, Brion F, Thybaud E, Hinfray N, Porcher JM. 2011. Adverse effects in wild fish living downstream from pharmaceutical manufacture discharges. Environ Int 37: 13421348. DOI: 10.1016/j.envint.2011.06.002.

Sentosa AA, Syam AR. 2011. Temporal distribution of mangrove crab (Scylla serrata) conditions in the waters of Mayangan Beach, Subang Regency, West Java. Jurnal Perikanan. 13 (1): 35-43. DOI: 10.22146/jfs.3060. [Indonesian]

Statistics Tarakan Municipality, 2018. Kota Tarakan dalam angka 2018 [City of Tarakan in 2018]. Statistics Tarakan Municipality, Tarakan. BPS Tarakan, North Kalimantan.

Szekely T, Weissing FJ, Komdeur J. 2014. Adult sex ratio variation: Implications for breeding system evolution. J Evol Biol 27: 15001512. DOI: $10.1111 /$ jeb. 12415

Taqwa A, Ali SA, Nessa MN, Niartiningsih A. 2018. Comparison of length-weight relationship of Bombay Duck (Harpadon nehereus) between Juata and Amal. Int J Curr Res Biosci Plant Biol 5: 11-14. DOI: $10.20546 /$ ijcrbp.2018.508.002

Wacker S, Mobley K, Forsgren E, Myhre LC, de Jong K, Amundsen T. 2013. Operational sex ratio but not density affects sexual selection in a fish. Evolution (NY) 67: 1937-1949. DOI: 10.1111/evo.12092

Wardiatno Y, Mashar A. 2010. Biological information on the mantis shrimp, Harpiosquilla raphidea (Fabricius 1798) (Stomatopoda, Crustacea) in Indonesia with a highlight. J Trop Biol Conserv 7: 6573.

Weatherley AH. 1972. Growth and Ecology of Fish population. Academic Press, USA

Widigdo B, Rukisah, Laga A, Hakim AA, Wardiatno Y. 2017. Carapace length-weight and width-weight relationships of Scylla serrata in Bulungan District, North Kalimantan, Indonesia. Biodiversitas 18 (4): 1316-1323. DOI: $10.13057 /$ biodiv/d180405. 